\title{
Evaluating the FDA regenerative medicine framework: opportunities for stakeholders
}

\author{
Elizabeth Richardson*,1, Farzana Akkas² \& Zubin Master ${ }^{3}$ iD \\ ${ }^{1}$ Director, Health Care Products Project, The Pew Charitable Trusts, 901 E Street, NW, Washington, DC 20004-2008, USA \\ ${ }^{2}$ Senior Research Associate, Health Care Products Project, The Pew Charitable Trusts, 901 E Street, NW, Washington, \\ DC 20004-2008, USA \\ ${ }^{3}$ Associate Professor, Biomedical Ethics Research Program \& Center for Regenerative Medicine, Mayo Clinic, 200 First Street, SW, \\ Rochester, MN 55905, USA \\ *Author for correspondence: Tel.: +1 202540 6457; erichardson@pewtrusts.org
}

\begin{abstract}
"There are also a range of cross-cutting interventions that could help to reduce the spread of misinformation surrounding the regenerative medicine field and improve informed consent practices for patients seeking such therapies."
\end{abstract}

First draft submitted: 2 June 2020; Accepted for publication: 17 July 2020; Published online: 20 August 2020

\section{Keywords: drug regulation $\bullet$ FDA $\bullet$ laws $\bullet$ regenerative medicine $\bullet$ unproven stem cell interventions}

Though stem cell products, gene therapies and other regenerative techniques have significant potential to 1-day treat traumatic injuries or serious disease, relatively few regenerative medicine products have been approved by the US FDA. However, this has not stopped hundreds of US businesses from selling unproven - and, in many cases, harmful - stem cell and regenerative interventions (SCRIs). Clinics around the world offer unproven SCRIs for a host of conditions to patients with few to no clinical options [1]. As of early 2017, there were estimates of 716 clinics offering SCRIs in the USA alone [2,3] - a number that has likely grown since then [4]. Using aggressive marketing primarily through patient testimonials and online information that is often exaggerated and incorrect, many clinics offer scientifically under- or untested interventions that have been shown to result in physical, emotional and financial harm [5-8]. Within the USA, there have been significant efforts made at the national, state and institutional level to regulate the market, educate physicians and inform patients. Most notable are the efforts made by the FDA in developing guidance to delineate more precisely which products would be required to go through the full drug development process, enforcing regulatory standards to curb the practices of riskier clinics and informing the scientific community and the public about responsible practices. Yet the smaller size of clinics, online nature of the marketing, limited resources of regulatory and oversight organizations and lack of overall coordination by multiple stakeholders has resulted in a patchwork of policy and regulatory efforts making it difficult for the FDA and other organizations to curtail the market $[3,9,10]$.

It is for this reason that the Pew Charitable Trusts conducted an evaluation of the FDA's framework and other policy approaches [10]. The goal of this project is to: understand how the framework was perceived among a select group of experts; describe any remaining areas of scientific or regulatory ambiguity that would need to be addressed; and identify next steps for FDA and other stakeholders to help ensure the safety and effectiveness of the regenerative therapies on the market. This evaluation included a formal legal analysis of the agency's guidance documents and the relevant statutes, as well as a series of 11 interviews with expert stakeholders (including practicing physicians who perform clinical stem cell research, legal experts on the regulation of human cell and tissue products [HCT/Ps]), a stem cell biologist and a bioethicist identified through purposive sampling. A full list of the interview subjects is available in the methodology section of the full report [10].

In this commentary, we will describe features of this market and highlight the findings to help inform scientists, manufacturers/sponsors and clinicians about the current regulatory space and enforcement climate. Because our analysis shows that FDA alone cannot fully protect the public from this rapidly growing market, we also describe 
opportunities and next steps for other public health stakeholders with an interest in ensuring a market of safe and effective regenerative medicine products and service lines.

\section{The current US regulatory \& policy climate of regenerative medicine}

The US market for unproven and unapproved SCRIs has grown rapidly despite the fact that FDA has clear statutory authority to regulate human cells, tissues as well as therapeutic products derived from human cells and tissues (collectively referred to as HCT/Ps) [11]. The level of regulatory scrutiny applied to these interventions depends on the risks associated with a given product. For example, HCT/Ps that are removed and implanted into the same person during the same surgical procedure are not generally subject to FDA regulation, provided that the HCT/Ps are not manipulated in any way beyond cleaning, sizing or shaping. This is often referred to as the 'same surgical procedure exemption,' and it includes things like skin grafts or coronary artery bypass surgery.

Other HCT/Ps are exempted from premarket review, but are subject to regulations intended to prevent the spread of infectious disease - these products are often referred to as 'Section 361 HCT/Ps,' after the relevant section of the Public Health Services Act that outlines the rules that apply to them. These products must meet four key criteria:

- Be 'minimally manipulated,' a concept which the agency defines as processing that does not alter the 'original relevant characteristics' of cells and tissues and for which it applies different regulatory criteria depending on whether the tissue is structural or nonstructural.

- Be intended for 'homologous use' - that is, when an HCT/P performs the 'same basic function' in the recipient as in the donor.

- Not be combined with other substances, except in limited, specific circumstances.

- Not have a system wide effect or depend on the metabolic function of living donor cells in order to function as intended, unless the product is for a patient's own use, is being donated to a first- or second-degree relative or is for reproductive use.

If an HCT/P does not meet the criteria for a section 361 product or the same surgical procedure exemption for example, if it is adipose tissue that is extracted from a patient and processed into stromal vascular fraction before reimplantation - it must go through FDA premarket approval (Figure 1). Depending on whether the HCT/P meets certain statutory criteria, the developer may be eligible to receive expedited status through the Regenerative Medicine Advanced Therapy designation, which is a regulatory pathway that is intended to facilitate the development and review process.

In November 2017, the agency released four new guidance documents that together make up its current regulatory framework for regenerative medicine [12-15]. At the time of publication, the agency also announced a 3 -year period of enforcement discretion for manufacturers of certain HCT/Ps that were already on the market, which is due to end in November 2020. This move was intended to give these companies time to consult with the FDA about their products and, if necessary, to begin moving them through the formal development and approval process.

At the same time, the agency noted that it would continue to pursue legal and regulatory actions against businesses marketing illegal products that threatened public health. The agency has since sought formal injunctions against two companies - one of which was granted; the other is still pending trial - and sent warning, untitled and other letters of correspondence to dozens more [16]. It has also taken a number of steps designed to facilitate the drug development process, including establishing a temporary program that allows manufacturers to obtain an informal, nonbinding assessment of whether their products will be required to file Biologics Licensing Application [17].

Despite these efforts, hundreds of clinics continue to market unproven and unapproved stem cell products directly to patients. These providers often claim that their products treat countless medical problems from arthritis to autism and multiple sclerosis. While there is little to no sound evidence that these products help patients, there are many examples where patients were harmed [18].

\section{Opportunities to clarify FDA oversight}

Pew's evaluation found that FDA's framework was generally perceived to be an efficient, risk-based approach to regulating the industry and was appropriately rigorous. Most interviewees agreed that it provided important clarity on how the agency would regulate HCT/Ps, but noted some remaining ambiguity regarding HCT/Ps that are 


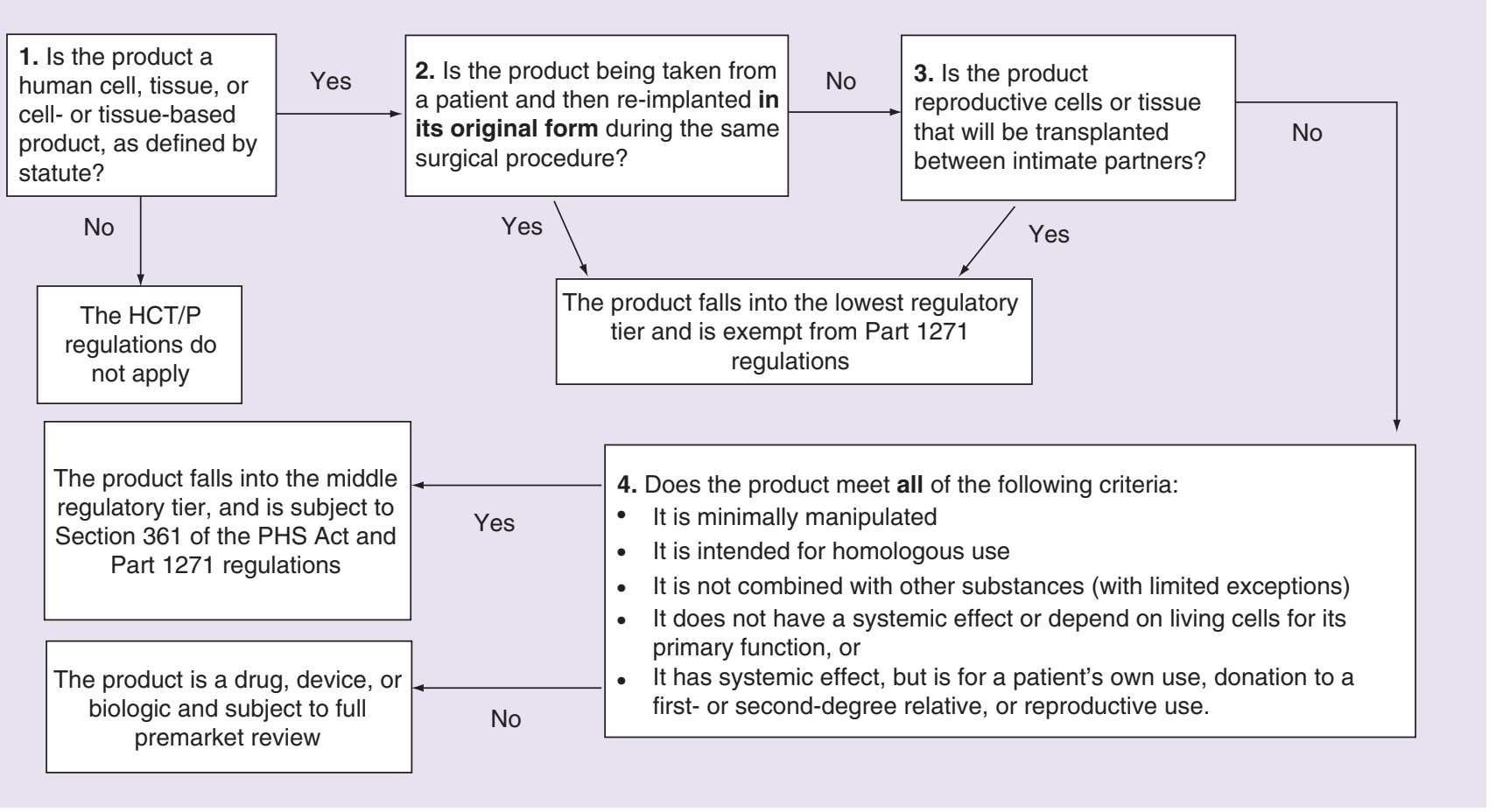

Figure 1. The level of FDA review applied to human cell and tissue products depends on several key parameters: whether the product meets the formal regulatory definition of an $\mathrm{HCT} / \mathrm{P}$; whether it meets the requirements for the same surgical procedure exemption, and if not; whether it meets the four criteria that allow it to be regulated solely under Section 361 of the Public Health Services Act and Part 1271 regulations, which are aimed at preventing disease transmission. If the product does not meet these qualifications, then the FDA will regulate it as a biological product and require the developer to submit a biologics licensing application.

HCT/P: Human cell and tissue product; PHS: Public Health Service.

Copyright $\odot 2019$ The Pew Charitable Trusts. All Rights Reserved. Adapted with permission from [10]. Any use without the express written consent of The Pew Charitable Trusts is prohibited. Information to generate original figure was obtained from [12].

transplanted within the same surgical procedure. Under that guidance, it remains unclear how the agency will approach products that remain in their original form but are used in a surgical procedure in ways that may deviate from their original function; for example, if a patient's own bone marrow stem cells are isolated and then used to treat, say, a neurological condition. Moving forward, the agency may want to provide additional examples - possibly in updated guidance documents - of how such products will be classified and regulated under the framework and update existing regulations as more products come through the development pipeline.

\section{Longer-term challenges for regulators}

There are more than 1000 regenerative medicine products in clinical trials worldwide, most of which are now in Phase II development [19]. The agency will need additional resources as well as adequately trained staff to handle the growing number of applications it will need to review [20]. In 2018, then Commissioner Gottlieb called for 50 additional reviewers for the Center for Biologics Evaluation and Research to help address the workload. But it will likely be challenging to attract and retain staff with the requisite level of expertise given the competing private-sector demand. And though the 21st Century Cures Act gave the FDA new hiring authorities designed to attract experienced professionals, there are still hundreds of vacancies across the agency [21].

The larger challenge, however, relates to the agency's efforts to enforce its regulations against businesses offering unapproved and potentially dangerous SCRIs to patients. While the 3-year period of enforcement discretion was intended to give legitimate businesses time to come into compliance with regulations, it also allowed the number of noncompliant actors to continue operating and potentially expand. It will be impossible for the agency to inspect them all, let alone bring legal cases against these providers. And it remains unclear how successful the agency will be in stemming their spread. The two stem cell firms that received legal injunctions in 2018, for example, continue to operate despite the agency's court victory last year. Others may simply move their operations outside of the 
USA [22]. But even though the agency cannot target all businesses that are violating the law, it can do more to target those engaged in particularly high-risk practices. The FDA can also seek out ways to support the efforts of other regulators and public health stakeholders who have a role to play in ensuring patient safety and protecting the legitimacy of the field more broadly.

\section{A potential role for other stakeholders}

There are opportunities for other regulators at the federal and state level to play a substantial role in halting and eventually reversing the spread of dangerous stem cell clinics. Both the Federal Trade Commission and state attorneys general can explore and pursue charges against clinics that engage in false and misleading advertising, as they have done in recent cases in California, Iowa, Nebraska, New York and North Dakota [23-25].

State governments can also help to protect patients by legislating in favor of stricter oversight. At least nine states have already introduced or passed legislation related to stem cell clinics, though it is unclear if any best practices have emerged, and not all state actions have been geared toward stronger patient protections [26-29].

State medical boards, which govern medical practice and can take disciplinary action against providers, could conduct proactive investigations of the clinics in their jurisdiction that offer risky regenerative and stem cell therapy treatments to patients and regularly monitor databases such as the National Practitioner Data Bank and the Physician Data Center, which harbor information on providers who have been the target of previous malpractice suits or disciplinary action $[30,31]$. The FDA can also assist in this effort, either by submitting warning letters to these databases or directly sending them to the relevant medical boards to inform them when the agency has raised concerns about a provider's practices.

Individual or class action lawsuits have also been undertaken by patients who have suffered damages, with claims including physical suffering, emotional distress, false advertising, misrepresentation and a lack of informed consent, among others [7]. This kind of civil litigation can help plaintiffs seek restorative justice and compensation for injuries and may also help to drive broader change in the industry by uncovering harmful business practices, raising public awareness about unapproved SCRIs through the media and pushing more businesses to comply with FDA regulation and other applicable laws. Civil litigation can also help facilitate FDA investigation if the discovery process in patient lawsuits is tried and reveals undisclosed violations of the law.

However, stem cell clinics have also used the threat of legal action, often to push back against criticism. In 2011, for example, the International Society for Stem Cell Research (ISSCR) launched a 'Submit a Clinic' website in an effort to better inform patients considering an SCRI. Patients were invited to submit advertisements by specific clinics or providers, which ISSCR proposed to examine more closely to help ensure there was appropriate oversight of the clinic. This information would then be posted to the ISSCR website [32]. Clinics quickly challenged the authority of the society to conduct such investigations, resulting in ISSCR abandoning the project to avoid possible legal action [32,33].

\section{Improving education \& limiting the spread of misinformation}

There are also a range of cross-cutting interventions that could help to reduce the spread of misinformation surrounding the regenerative medicine field and improve informed consent practices for patients seeking such therapies. While many scientific organizations have played a significant role in attempting to improve information for patients and the general public, overall these efforts have been sparse. Most patient education has been in the form of online information on websites and patient handbooks and videos [34-41]. One recent study has shown that online resources may influence one's intention to consider a riskier unproven SCRI, albeit for a short time after reading the resource [42]. Considering the market is driven by misinformation and patients are avid information seekers [43-48], there is a need for more accurate patient education as well as interventions designed to elicit health behavior change [49].

More recently, two studies have examined the nature of expert consultations to inform patients about SCRIs. Both Stem Cells Australia, a stem cell science initiative established by the Australian government and EuroStemCell, a reliable source of information on SCRIs, offer online and caller platforms to address patient queries about SCRIs related to their conditions [48]. In 2011, Mayo Clinic established the Regenerative Medicine Consult Service that provides information and navigates patients to evidence-based SCRIs [45,47]. Strategies of patient counseling are likely to be tremendously helpful to address patient questions and concerns about SCRI and patient booklets and online information can complement such efforts to help correct misinformation. 
In addition to patient education, efforts should also be made to better inform physicians about the science behind these interventions, including their risks [50,51]. About half the physicians providing unproven SCRIs are unqualified [9,52] but continue to offer them to patients regardless. Several organizations have entered the business of teaching physicians how to apply stem cell interventions to patients. It is not always clear whether such training is intended to prepare physicians for entering research or practice, but some advertisements do discuss the prospects of profit and patient demand over SCRIs [53]. While there have been legitimate efforts to educate medical and science students about stem cell and regenerative medicine, [54-56], aside from one report by the International Society for Stem Cell Research [57], there has been no continuing medical education or other training developed to educate practicing physicians considering getting into the stem cell business.

Online and other forms of education and counseling can further complement regulatory and policy efforts to ensure regulatory compliance in business practices and provide information and correct misinformation for patients, physicians and the public. Online advertising platforms can also take steps to reduce the spread of misinformation related to SCRIs. Google, for example, recently banned advertisements marketing unapproved medical therapies, including SCRIs [58]. Other companies that serve as advertising platforms should consider following their lead.

\section{Conclusion}

While progress has been made by the FDA on implementing the various components of the new regulatory framework, its impact on the regenerative medicine industry - and on the successful development of safe, effective and innovative new therapies - remains to be seen. For FDA to succeed in its efforts in bringing the industry into compliance, it will be important for the agency to continue prioritizing oversight and enforcement. However, given the size of the current market for these products, addressing the problem will require a combination of different interventions targeting a range of audiences and stakeholders in the federal, state and private sectors.

\section{Summary points}

- Human cells, tissues and cell- and tissue-based products (HCT/Ps) - which play a key role in the field of regenerative medicine - may have the potential to treat a range of medical illnesses and conditions, but relatively few have been approved by the US FDA.

- However, the market for unproven and unapproved stem cell and regenerative interventions (SCRIs) is large and growing, posing a risk to public health and potentially undermining public confidence in the regenerative medicine field.

- In 2017, the FDA released an updated regulatory framework that aimed to clarify its policies regarding the regulation of $\mathrm{HCT} / \mathrm{Ps}$ and in particular, how it would determine which products would be subject to full premarket review.

- In order to give manufacturers time to come into compliance with this framework, the agency also announced a 3-year enforcement discretion period, which will end in November 2020. During this time, the FDA is enforcing its regulations only against those products that pose a significant safety concern.

- Interviews with a range of experts revealed that FDA's framework is science-based and provides helpful clarity for the field, but that additional clarity is needed with regard to how the agency will regulate certain interventions. Interviewees also raised concerns about FDA's ability to adequately enforce its framework given the number of businesses currently offering unapproved and risky SCRIs.

- There is substantial opportunity for other public health stakeholders to play a role in protecting patients from harmful products. This includes legal action by federal and state agencies like the Federal Trade Commission and state attorneys general offices; state legislation to tighten regulation of clinics; better oversight by state medical boards; and individual private action against clinics.

- Scientific and professional organizations can also take steps to improve both patient and provider education about unapproved SCRIs and increase awareness about their risks. Companies that manage online platforms can support these efforts by doing more to limit the spread of misinformation and prevent clinics from advertising their products on their platform.

Financial \& competing interests disclosure

The authors thank the Pew Charitable Trusts for funding the original research on which this Commentary is based. The authors have no other relevant affiliations or financial involvement with any organization or entity with a financial interest in or financial conflict with the subject matter or materials discussed in the manuscript apart from those disclosed.

No writing assistance was utilized in the production of this manuscript. 
Open access

This work is licensed under the Attribution-NonCommercial-NoDerivatives 4.0 Unported License. To view a copy of this license, visit http://creativecommons.org/licenses/by-nc-nd/4.0/

\section{References}

Papers of special note have been highlighted as: • of interest; $\bullet \bullet$ of considerable interest

1. Sipp D, Caulfield T, Kaye J et al. Marketing of unproven stem cell-based interventions: a call to action. Sci. Transl. Med. 9(397), 1-5 (2017).

2. Turner L. The U.S. direct-to-consumer marketplace for autologous stem cell interventions. Perspect. Biol. Med. 61(1), 7-24 (2018).

- It provides an overview of the stem cell marketplace.

3. Turner L, Knoepfler P. Selling stem cells in the USA: assessing the direct-to-consumer industry. Cell Stem Cell 19(2), 154-157 (2016).

4. Knoepfler P. Rapid change of a cohort of 570 unproven stem cell clinics in the USA over 3 years. Regen. Med. 14(8), 735-740 (2019).

5. Bauer G, Elsallab M, Abou-El-Enein M. Concise review: a comprehensive analysis of reported adverse events in patients receiving unproven stem cell-based interventions. Stem Cells Transl. Med. 7(9), 676-685 (2018).

6. Hawke B, Przybylo A, Paciulli D, Caulfield T, Zarzeczny A, Master Z. How to peddle hope: an analysis of YouTube patient testimonials of unproven stem cell treatments. Stem Cell Rep. 12(6), 1186-1189 (2019).

7. Horner C, Tenenbaum E, Sipp D, Master Z. Can civil lawsuits stem the tide of direct-to-consumer marketing of unproven stem cell interventions? NPJ Regen. Med. 3(1), 1-5 (2018).

8. Macron AR, Murdoch B, Caulfield T. Fake news portrayals of stem cells and stem cell research. Regen. Med. 12(7), 765-775 (2017).

9. Fu W, Smith C, Turner L, Fojtik J, Pacyna J, Master Z. Characteristics and scope of training of clinicians participating in the US direct-to-consumer marketplace for unproven stem cell interventions. JAMA 321(24), 2463-2464 (2019).

- It examines the characteristics and scope of training of clinicians performing unproven stem cell procedures.

10. The Pew Charitable Trusts. FDA's framework for regulating regenerative medicine will improve oversight (2019). www.pewtrusts.org/en /research-and-analysis/reports/2019/10/17/fdas-framework-for-regulating-regenerative-medicine-will-improve-oversight

-. Our commentary is largely based on this report, which is an analysis of FDA's framework for regulating regenerative medicine.

11. Marks P, Gottlieb S. Balancing safety and innovation for cell-based regenerative medicine. N. Engl. J. Med. 378, $954-959$ (2018).

- It discusses FDA's statutory authority to regulate regenerative medicine.

12. U.S. Food and Drug Administration. Regulatory considerations for human cells, tissues, and cellular and tissue-based products: minimal manipulation and homologous use: guidance for Industry and Food and Drug Administration Staff (2017). www.fda.gov/downloads/bi ologicsbloodvaccines/guidancecomplianceregulatoryinformation/guidances/cellularandgenetherapy/ucm585403.pdf

-. The four final guidance documents that together make up FDA's regenerative medicine policy framework.

13. U.S. Food and Drug Administration. Same surgical procedure exception under 21 CFR 1271.15(b): questions and answers regarding the scope of the exception (2017).

www.fda.gov/downloads/biologicsbloodvaccines/guidancecomplianceregulatoryinformation/guidances/tissue/ucm419926.pdf

-• The four final guidance documents that together make up FDA's regenerative medicine policy framework.

14. U.S. Food and Drug Administration. Evaluation of devices used with regenerative medicine advanced therapies: guidance for industry (2019). www.fda.gov/downloads/BiologicsBloodVaccines/GuidanceComplianceRegulatoryInformation/Guidances/Cellulara ndGeneTherapy/UCM585417.pdf

-• The four final guidance documents that together make up FDA's regenerative medicine policy framework.

15. U.S. Food and Drug Administration. Expedited programs for regenerative medicine therapies for serious conditions: guidance for industry (2019). www.fda.gov/downloads/BiologicsBloodVaccines/GuidanceComplianceRegulatoryInformation/Guidances/Cellulara ndGeneTherapy/UCM585414.pdf

-• The four final guidance documents that together make up FDA's regenerative medicine policy framework.

16. U.S. Food and Drug Administration. FDA sends warning to companies for offering unapproved umbilical cord blood products that may put patients at risk (2017). www.fda.gov/news-events/press-announcements/fda-sends-warning-companies-offering-unapproved-umbili cal-cord-blood-products-may-put-patients-risk

17. U.S. Food \& Drug Administration. FDA announces temporary streamlined program to help manufacturers of human cell, tissue, and cellular and tissue-based products - including stem cell treatments - understand the appropriate regulatory pathways for their products (2019). www.fda.gov/news-events/fda-brief/fda-brief-fda-announces-temporary-streamlined-program-help-manufacturers-h uman-cell-tissue-and

18. The Pew Charitable Trusts. Appendix B. Examples of adverse events associated with unapproved stem cell treatments (2019). www.pewtrusts.org/-/media/assets/2019/10/fdasframeworkforregulatingregenerativemedicine_appendixb.pdf

19. Alliance for Regenerative Medicine. Q3 2019 data report (2019). https://alliancerm.org/publication/q3-2019-data-report/ 
20. Swetlitz I. Gottlieb pushes for funding to speed gene therapy reviews. STAT (2018). www.statnews.com/2018/11/16/gottlieb-pushes-for-funding-to-speed-gene-therapy-reviews

21. U.S. Food \& Drug Administration. FDA 21st century cures workforce planning report to Congress (2018). www.fda.gov/media/114163/download

22. Grady D. A judge rules against one stem-cell clinic. There are hundreds of them. The New York Times (2019). www.nytimes.com/2019/06/10/health/stem-cells-fda.html

23. U.S. Federal Trade Commission. FTC stops deceptive health claims by a stem cell therapy clinic (2018). www.ftc.gov/news-events/press-releases/2018/10/ftc-stops-deceptive-health-claims-stem-cell-therapy-clinic?utm_source=govdelivery

24. Office of the New York State Attorney General. Attorney General James announces lawsuit against New York City stem cell clinic for scamming vulnerable patients out of thousands (2019).

https://ag.ny.gov/press-release/2019/attorney-general-james-announces-lawsuit-against-new-york-city-stem-cell-clinic

25. Emerson B. Bismarck clinic agrees to repay patients $\$ 20 \mathrm{~K}$, discontinue stem cell injections. The Bismarck Tribune (2018). https://bismarcktribune.com/news/state-and-regional/bismarck-clinic-agrees-to-repay-patients-k-discontinue-stem-cell/article_4b184 869-2775-5b02-94cf-ce18f61abef3.html

26. North Carolina. House Bill 934. Right to try adult stem cell treatments (2019). https://trackbill.com/bill/north-carolina-house-bill-934-right-to-try-adult-stem-cell-treatments/1741578/

27. Vermont. House Bill 626/Senate Bill 252. An act relating to administering stem cell products not approved by the U.S. Food and Drug Administration (2020). https://legislature.vermont.gov/bill/status/2020/H.626; https://legislature.vermont.gov/Documents/2020/Wor kGroups/Senate\%20Health\%20and\%20Welfare/Bills/S.252/Drafts, \%20Amendments, \%20and\%20Summaries/S.252 Jennifer\%20Carbee As\%20Recommended\%20by\%20Senate\%20Health\%20and\%20Welfare\%20 3-13-2020.pdf

28. Mississippi. Senate Bill 2830. Right-to-Try Act; Revise definition to include traumatic injury and adult autologous mesenchymal stem cells (2020). http://billstatus.ls.state.ms.us/documents/2020/pdf/SB/2800-2899/SB2830IN.pdf

29. The Pew Charitable Trusts. Appendix E. Sample state legislation targeting stem cell businesses, procedures. FDA's framework for regulating regenerative medicine will improve oversight (2019). www.pewtrusts.org/-/media/assets/2019/10/fdasf rameworkforregulatingregenerativemedicine_v2.pdf

30. Federation of State Medical Boards. Physician data center (2019). www.fsmb.org/PDC

31. U.S. Department of Health and Human Services, U.S. Department of Health and Human Services, Health Resources and Services Administration. NPDB Guidebook (2018). www.npdb.hrsa.gov/resources/NPDBGuidebook.pdf

32. Ledford H. Stem-cell scientists grapple with clinics. Nature 474, 550 (2011).

33. Knoepfler P. Stem cell scientists KO'd in round one versus unproven clinics: where's the FDA? Niche (2011). https://ipscell.com/2011/06/stem-cell-scientists-kod-in-round-one-versus-unproven-clinics-wheres-the-fda/

34. Stem Cell Australia. The Australian stem cell handbook (2015). www.stemcellsaustralia.edu.au/AboutUs/Document-Library/The-Australian-Stem-Cell-Handbook.aspx

35. EuroStemCell. Education (2020). www.eurostemcell.org/landing/education-resources

36. International Society for Stem Cell Research. Informed consent standard for stem cell-based interventions offered outside of formal clinical trials (2019). www.isscr.org/docs/def ault-source/policy-documents/isscr-informed-consent-standards-for-stem-cell-based-interventions.pdf

37. International Society for Stem Cell Research. A closer look at stem cell therapies (2020). www.closerlookatstemcells.org

38. International Society for Stem Cell Research. Patient handbook on stem cell therapies (2008). www.isscr.org/docs/default-source/patient-handbook/isscrpatienthandbook.pdf

39. Master Z, Caulfield T. Patient booklet: what you need to know about stem cell therapies (2014). www.researchgate.net/profile/Zubin_Master2/publication/264397034_Patient_Booklet_What_you_need_to_know_about_stem_cell_thera pies/links/53db612a0cf2631430cb4527/Patient-Booklet-What-you-need-to-know-about-stem-cell-therapies.pdf

40. Stem Cell Network. Stem cell education reaching out to students and the public (2020). https://stemcellnetwork.ca/stem-cells/stem-cell-education/

41. U.S. Food \& Drug Administration. FDA warns about stem cell therapies (2019). www.fda.gov/consumers/consumer-updates/fda-warns-about-stem-cell-therapies

42. Unsworth D, Mathias J, Dorstyn D, Koblar S. Are patient educational resources effective at deterring stroke survivors from considering experimental stem cell treatments? A randomized controlled trial. Eur. PMC 103(7), 1373-1381 (2020).

43. Master Z, Zarzeczny A, Rachul C, Caulfield T. What's missing? Discussing stem cell translational research in educational information on stem cell "tourism". J. Law Med. Ethics 41(1), 254-268 (2013).

44. Petersen A, Tanner C, Munsie M. Between hope and evidence: how community advisors demarcate the boundary between legitimate and illegitimate stem cell treatments. SAGE J. 19(2), 188-206 (2014). 
45. Smith C, Martin-Lillie C, Higano JD et al. Challenging misinformation and engaging patients: characterizing a regenerative medicine consult service. Regen. Med. 3(15), 1427-1440 (2020).

46. Tanner C, Petersen A, Munsie M. 'No one here's helping me, what do you do?': addressing patient need for support and advice about stem cell treatments. Regen. Med. 12(7), 791-801 (2017).

47. Zarzeczny A, Atkins H, Illes J et al. The stem cell market and policy options: a call for clarity. J. Law Biosci. 5(3), 743-758 (2018).

48. Zarzeczny A, Tanner C, Barfoot J, Blackburn C, Couturier A, Munsie M. Contact us for more information: an analysis of public enquiries about stem cells. Regen. Med. 14(12), 1137-1150 (2019).

49. Master Z, Smith C, Tilburt JC. Informed consent for stem cell-based interventions. JAMA 323(9), 893 (2020).

- It reports on the standards of informed consent for patients seeking stem cell interventions outside a clinical trial from the International Society for Stem Cell Research.

50. Bowman M, Racke M, Kissel J, Imitola J. Responsibilities of health care professionals in counseling and educating patients with incurable neurological diseases regarding "stem cell tourism": Caveat Emptor. JAMA Neurol. 72(11), 1342-1345 (2015).

51. Weiss DJ, Turner L, Levine AD, Ikonomou L. Medical societies, patient education initiatives, public debate and marketing of unproven stem cell interventions. Cytotherapy 20(2), 165-168 (2018).

52. Frow EK, Brafman DA, Muldoon A et al. Characterizing direct-to-consumer stem cell businesses in the Southwest United States. Stem Cell Rep. 13(2), 1-7 (2019).

53. Empire Medical Training. Intergrative stem cell \& regenerative therapies (2020). www.empiremedicaltraining.com/antiaging-regenerative-workshops/stem-cell-training/

54. Bajek A, Drewa T. Should we teach regenerative medicine during undergraduate education? Stem Cell Stud. 1(14), 90 (2011).

55. Knoepfler P. Call for fellowship programs in stem cell-based regenerative and cellular medicine: new stem cell training is essential for physicians. Regen. Med. 8(2), 223-225 (2013).

56. Wyles S, Hayden R, Meyer F, Terzic A. Regenerative medicine curriculum for next-generation physicians. NPJ Regen. Med. 4(3), 1-5 (2019).

57. International Society for Stem Cell Research. Stem cell based clinical trials: practical advice for physicians and ethics/institutional review boards (2018).

www.isscr.org/docs/default-source/clinical-resources/isscr-stem-cell-based-clnical-trials-practical-advice_final_23jan2018.pdf?sfvrsn=2

58. Google Ads. A new policy on advertising for speculative and experimental medical treatments (2019).

https://support.google.com/google-ads/answer/9475042 